UNTAG Law Review (ULREV)

Volume 2, Issue 1, May 2018, PP 57-69

ISSN 2549-4910 (online) \& ISSN 2579-5279 (print)

http://jurnal.untagsmg.ac.id/indeks.php/ulrev/indeks

www.fakhukum.untagsmg.ac.id

\title{
CRIMINAL POLICIES BASED ON RELIGIOUS VALUES IN TACKLING CYBER ADULTERY
}

\author{
Any Ismayawati \\ Email : any.ismayawati@yahoo.com
}

\begin{abstract}
Research on crime-based policies of religious values in tackling cyber adultery aims to determine whether cyber adultery can be used as criminal as well as to know what basis can be used to criminalize cyber adultery. For this research to achieve the desired result, this research uses qualitative research tradition, with constructivism paradigm, with socio legal approach and data analysis using hermeneutic approach method, phenomenology, comparison and policy. The results show that cyber adultery has become a very disturbing problem for society, because the impact of adultery causes disharmony of household, divorce and even moral degradation of the nation. Cyber adultery poses various problems in society, but there is no rule / law that specifically prohibits cyber adultery so difficult to overcome. Based on the results of the research can be concluded that cyber adultery can be made criminal act because it is not in accordance with the collective values embraced by the Indonesian nation and Causes losses matriil and morale for the nation of Indonesia. The foundation that can be used to make cyber adultery as a crime is the religious values that exist in Indonesia
\end{abstract}

Keywords : Cyber Adultery, Criminalization, Values Of Religion, Science And Technology

\section{INTRODUCTION}

Science and Technology was created to facilitate life and to realize the welfare of mankind. Nowadays, society can not escape from science and technology in every movement of life, even the use of science and technology has become a necessity. On the other hand shows, that from several research results known advances in science and technology have a significant influence on the increase of crime rate. ${ }^{1}$ The ease created by technology in all spheres of life

1 Widyopramono, Kejahatan di Bidang Komputer, Jakarta, Pustaka Sinar Harapan, 1994, p. 28 Sudarto, Hukum Pidana dan Perkembangan Masyarakat. Kajian terhadap Pembaharuan Hukum Pidana, Bandung : Sinar Baru, 1983, p. 32. 
also affects the ease of doing evil. The misuse of technology to commit crimes that came to be known as science and technology crimes severely damage human life, making it counter productive with the goal of creating science and technology itself. This is because the technological changes has an indirect effect on the behavior of the attitude of the community. ${ }^{2}$

It is therefore acceptable that the revolutionary development of science and technology as it currently exerts a tremendous influence on the evolution of crime, since the development of evil will always be in line with the development of society itself.

Based on that then when doing reconstruction of a law, should be prepared in order to follow the development of society. One of the things that must be considered in following the development of society is the development of knowledge and technology, because science and technology are very influential on the behavior of society, even the development of science and technology today has been able to create a new world called the virtual world or cyberspace ${ }^{3}$

The birth of the new world gave birth to a new community of cyber community. In this new society new behaviors emerge according to the nature of the new society. The emergence of this new form of society, also has an impact on the emergence of new crimes. In connection with the emergence of these crimes it is necessary a new law also to overcome them.

At this time, in solving the crimes that arise as a result of the new world is used the existing law. The use of existing law in tackling crime from cyber world is not complete. There are some crimes that can not be resolved if using the law.

Such ineffectiveness and lawlessness are contrary to the function and purpose of law. The law should be able to function as a social control and social engineering and be able to realize the welfare of society.

In this regard, it is necessary to conduct research in order to obtain a basis in performing legal reconstruction, so that the law as a social control can solve all the problems that arise in society.

This study focused on the reconstruction of adultery offense. Because in cyberspace appear crimes related to adultery. This crime is very disturbing to the public because the greatest impact of this crime is the moral degradation of the nation. This research uses qualitative research tradition, constructivism paradigm with socio-legal approach. The data obtained were assessed using hermeneutic approach, phenomenology, comparison and policy.

2 Sudarto, Hukum Pidana dan Perkembangan Masyarakat. Kajian terhadap Pembaharuan Hukum Pidana, Bandung : Sinar Baru, 1983, p. 32.

3 Cyberspace is an imaginary space or an artificial virtual space, where everyone does everything that can be done in everyday social life in new ways. See inside Dwi Haryadi, Kebijakan Integral Penanggulangan Cyberporn di Indonesia, Yogyakarta : Penerbit Lima, 2013, p.2. 


\section{Criminalization of Cyber adultery}

The first thing to known to criminalize cyber adultery is regarding the limits of deeds included in cyber adultery category. Referring to the cyber sex understanding of some of the opinions expressed above, it can be concluded that cyber adultery includes deeds ${ }^{4}$

1. The use of the Internet for sexual purposes.

2. The use of computers for any form of expression or sexual satisfaction.

3. A new type of intimacy, which can also be interpreted as a new form of adultery or illicit sexual relations.

4. Can be viewed as a form of virtual sex expression or gratification.

5. A virtual sex encounter or sex online.

6. Meetings of two or more people connected via the Internet network by sending sexual messages or describing sexual experiences to arouse sexual feelings / fantasies, resulting in masturbation.

7. Seen from the point of impact, many negative impacts for the perpetrators themselves, crush /destroy the harmony of marriage relationships, damage the family system and damage / harm the children.

Based on the cyber sex category then the limitations of cyber adultery are as follows:

1. The means used is internet network.

2. The act is done with the aim to gain sexual satisfaction.

3. Conducted with a non-legal partner.

4. Seek sexual satisfaction in the virtual world.

The first thing to do is to plan for the future to deal with or deal with the crime, including formulating actions that can be criminalized, and formulating the sanctions that can be imposed on the offender. These stages are known as criminal politics or criminal policies. ${ }^{5}$ The first step in criminal policy is to criminalize to establish an act of being a criminal offense, and the final step is to establish a form of sanction against the offense of the offense.

4 Barda Nawawi Arief, Tindak Pidana Mayantara Perkembangan Kajian Cyber Crime di Indonesia, Jakarta : PT. Rajagrafindo Persada, , 2006, p. 186-107

5 According to Barda Nawawi Arief Criminal or criminal politics policy means planning for the future to deal with or deal with issues related to crime, including in formulating actions that can be criminalized and formulating sanctions to be imposed on the offender. see Barda Nawawi Arief, Pendekatan Keilmuan dan Pendekatan Religius dalam Rangka Optinalisasi Penegakan Hukum (Pidana) di Indonesia, Semarang : Badan Universitas Diponegoro Press, 2010,p. 11 
As explained before, that one of the problems that arise in the presence of cyber community is the emergence of cyber adultery. In handling cyber adultery this raises two opinions. The first opinion, that cyber adultery is the same as adultery in the real world so that in dealing with it can be used existing law, namely Article 284 of the Criminal Code. The second opinion says that cyber adultery is adultery in a new form, so it requires a new rule in overcoming it.

According to David Goldberg, cyber $\operatorname{sex}^{6}$ is an act of adultery in cyberspace (cyber adultery), as well as the opinion of Barda Nawawi Arief based on the free encyclopedia wikipedia stated that Cyber sex or computersex is a virtual encounter / virtual between two or more people connected. Through the Internet network by sending messages of sexual messages depicting a sexual experience.

In addition to some of these opinions, Cyber adultery can be categorized as adultery with the following explanation ${ }^{7}$ :

1. Article 284 not only provides a juridical definition of what is meant by adultery.

2. There is an element of sexual intercourse / copulation physically only a general opinion and opinion developed in theory / doctrine and jurisprudence.

3. General opinion / doctrine / jurisprudence is based on the paradigm / concept of action in the material / physical sense, while now there is the development of the paradigm / concept of action in a functional and scientific way.

4. The interpretations based on the functional paradigm and the scientific paradigm of some legal sense (such as "deeds", "goods", "legal subjects", "people") have been developed / used in the practice of law making and jurisprudence.

5. In the article source on the internet entitled cyber sex there are organizations out there to help you stated that cyber sex is adultery (adultery). In essence in the article above adultery is as follows: "For a married person, doing cyber sex activity is a form of adultery (for a married person to engage in this activity). Seen from the legal point of view, it is a gray area, but it is only because the court can not pursue the time. The court may establish cyber sex as adultery or as a form of abandonment. Morally viewed, is clearly a form of cheating, and from a religious standpoint it is a form of adultery".

6 In the opinion of David Goldberg in Barda Nawawi Arief, Tindak Pidana Mayantara ... Ibid, p.179. cyebr sex is the use of internet for sexual. Similarly, Greenfield says that Cyber sex is the use of computers for every form of expression or sexual satisfaction and a new form of intimacy. Meanwhile, according to Barda Nawawi Arief who quotes English-Indonesian dictionary, that intimate relationship or intimacy (intimacy) can also mean sexual relations or adultery.

7 Barda Nawawi Arief, Tindak Pidana Mayantara ....Ibid, p. 188-189 
6. Viewed from the standpoint of Islam, it is clear that cyber sex is adultery. This was stated by Dr. Muzammil H. Shiddiqi (former president of the Islamic Society of North America) when answering someone's question via the internet, whether cyber sex and phone sex are adultery? He responded as follows.

"Zina accourding to Shari'ah is any illicit sexual intercourse. Thus pre-marital sex, extra marital sex and homosexuality are allconsidered Zina according to Islamic law. Zina is a major $\sin$ (Kabirah); It is absolutely forbidden. Islam does not only forbid illicit sexual intercourse, but also forbids anything that leads to this sin and crime. Cyber sex, phone sex, etc. Are those activities that can lead to Zina".

Although some of these opinions indicate that cyeber adultery can be categorized as adultery, so it is possible to use Article 284 of the Criminal Code, but in order to realize legal certainty and legal unification, it is necessary to establish a regulation governing Cyber Adultery. Similarly, if analyzed by using progressive law, ${ }^{8}$ if Article 284 of the Criminal Code is difficult to apply to cyber adultery, then it is not the human being who is forced to adapt the law but the law which must adapt to human development.

In this regard, when reconstructing adultery delus should consider the development of science and technology, because the development of science and technology is very influential on human life and the development of society, while the development of law is influenced by the development of society.

Regarding the stages of criminal policy, the first stage is to criminalize. In the opinion of Barda Nawawi Arief, ${ }^{9}$ when criminalizing Cyber Adultery must be able to counteract the negative side / impact of all aspects of the life field related to Cyber Adultery. It is hoped that criminalizing Cyber Adultery will be able to cope with the nation's moral damage, prevent domestic rifts / prevent divorce.

Based on the lattice / criminalization checks in the opinion of Sudarto ${ }^{10}$, the first consideration

8 Satjipto Rahardjo, Membedah Hukum Progresif, Jakarta : PT Kompas Media Nusantara, 2006, p.4

9 Barda Nawai Arief, Pornografi Pornoaksi dan Cybersex-Cyberporn, Semarang: Pustaka Magister, 2011, p. 6-7

10 See in Sudarto, Hukum dan Hukum Pidana, Bandung :Alumni 1981, p.44-48, The grid for criminalization is as follows:

1. The use of criminal law should take account of the national development objective, namely to create a just and prosperous society equally material and spiritual based on Pancasila; In this respect, the use of criminal law aims to tackle crime and hold suspension of the countermeasures themselves, for the welfare and protection of society.

2. The act which is attempted to be prevented or overcome by criminal law shall be "undesirable act", that is, the act of bringing harm (matriil and or spiritual) to the citizens.Penggunaan hukum pidana harus pula memperhitungkan prinsip "biaya dan hasil" (cost benefit principle).

3. The use of criminal law should also consider the capacity or ability of the workforce of law enforcement agencies, ie do not let there is an overload of tasks (overbelastingi). 
of the criminalized objective is to create a just and prosperous society equally material based on Pancasila. This means that the criminalization of adultery in cyberspace does not only consider the impact of material losses, but 1 the spiritual / moral loss. This is in accordance with the purpose of national development that is to build Indonesian people, both physical and spiritual (moral). As it is known that the biggest disadvantage of cyber adultery is moral harm, even the moral degradation of the nation.

The second signposts when criminalizing deeds is that the action is not desired by the community for bringing material and spiritual harm. Similarly, Cyber adultery is an action that impacts very harmful to society, in terms of material and morale, while the greatest loss is from the moral side (spiritual). ${ }^{11}$

In the criminalization of cyber adultery must also pay attention to the costs and results as the third signs in the criminalization. Seeing the losses incurred from cyber adultery is more of a spiritual loss then criminalizing cyber adultery will not cost much more than the result, due to a spiritual loss which in this case is the nation's moral degradation is an invaluable loss.

The last signs in the criminalization of cyber adultery is not to have the officer overloaded. This is related to professionalism, and the duty of the state in providing protection to its citizens and realizing the welfare of its citizens. That is, the state in the recruitment of officers must be truly professional and the responsibility of the state to appoint sufficient officers in order to provide protection and realize the welfare of its citizens.

Cyber adultery is one form of high tech crime, therefore in dealing with it must be used technology / scientific, cultural / cultural, Moral / educational approach. ${ }^{12}$ As well as in the formulation stage of the rule by criminalizing, the three approaches are also used.

Based on that, in reconstructing of adultery violation related to the development of science and technology, the issue of propriety in society and its value becomes a measure in society to serve as a guideline in criminalizing, in addition to some criteria or general requirements in criminalizing.

In that case Sudarto said that the measure to criminalize an action depends on the values and collective views contained in the community about what is good, right, beneficial or otherwise. It can be said that society and religious views on morality are very influential in the formation

11 See in Barda Nawawi Arief, Tindak Pidana Mayantara...Op.Cit, p.181. The results of research conducted by Peter David Goldberg menunjuukkan that cyber adultery actors change behavior, which resulted in family relationships become unharmed that eventually divorce occurs. The results of this study also mentioned that the number of divorces increased as a result of one spouse or both doing cyber adultery.

12 See in Barda Nawawi Arief, Tindak Pidana Mayantara ...Op.Cit, p.182-183 
of law, especially the criminal law. ${ }^{13}$ In Indonesian society, any form of adultery is a moral act contrary to the norm of Indonesian propriety, violates religious and customary values. Similarly adultery or cyber-adultery, which is not only a betrayal of loyalty to a spouse, is not merely a form of blasphemy, but also a violation of religious norms, and norms of decency.

Referring to the results of research indicates that cyber adultery is the undesirable act of society, because it brings losses (material and / or spiritual / morale) to the people. Losses in terms of material, among others, cyber adultery is one of the factors causing divorce. In spiritually / morally disadvantage that resulted in making the household is not harmonious, eliminating the confidence in someone, making someone become a social and the biggest impact is the moral degradation of the nation. The impact of such as not only leads to material losses and not only the individuals who are harmed but the moral losses are also experienced by community.

Based on the result of research related to signs of criminalization, it is very basic if cyber adultery is criminalized, so it becomes clear that cyber adultery is a crime.

\section{The Value of Religion as the Base of Cyber Adultery Criminalization}

Cyber adultery or adultery in this virtual world get sexual satisfaction not with a legitimate partner but through the internet. Based on this understanding it is not easy to criminalize cyber adultary, therefore in doing criminalization must be done with technology / scientific, cultural / cultural, and moral / educative approach. ${ }^{14}$

The moral approach can be done by using religious norms, because religion is the moral foundation for its followers. This moral approach is in accordance with the opinion of Sudarto and Barda Nawawi Arief that in the criminalization must be based on the values and collective views of the community, the values and collective views of the Indonesian nation are religious values, then in the criminalization of cyber adultery based on value- The religious values that guide the life of the Indonesian nation, and are believed to be true. Efforts to make religious norms as basic ideas in the development of national law is one step in criminal policy.

In the norms of religion that exist in Indonesia, the notion of adultery is not only intercourse between men and women, but every act that can encourage a person to do intercourse with her partner is not legitimate. This understanding can be used as a basis in the prohibition of adultery in cyberspace. It means here that adultery is not just copulation that is physically met.

The first research was conducted on the values of Islam with the consideration that the majority of Indonesian people are Muslim. As it is known that Islamic values are derived from the

13 Sudarto, Op.Cit, Bandung: Sinar Baru, 1983, p. 67.

14 See in Barda Nawawi Arief, Tindak Pidana Mayantara....Op.Cit, 2005, p.90. 
Qur'an and Hadith, it will be studied by the Qur'an and Hadith to obtain norms that can be used as basic ideas in criminalizing cyber adultery.

As the basis of criminalization of cyber adultery can be used Al-Qur'an Surat Al-Isra '(17): 32, namely "And do not approach adultery, adultery is a cruel act and a bad way". In the verse it says "do not approach adultery", the meaning contained from the verse is a prohibition of committing acts that lead or cause people to commit adultery, further meaning is more forbidden acts of adultery, because approaching alone is prohibited. ${ }^{15}$

In the commentary put forward by M.Quraish Shihab said do not approach adultery by doing things, though in the form of fantasizing that can lead you falling into ugliness. The approaching prohibition also implies a prohibition for not falling into the seduction of something that potentially leads to the step of committing adultery. ${ }^{16}$ The opinion can be used as a basic idea in criminalizing cyber adultery, because in tafsir it is said "though in the form of imagining". While cyber adultery is a form of adultery by fantasizing about committing adultery.

In Islamic law mentioned some actions that can lead someone to commit adultery, among others, is to look at women who are not lawful for him. The commandment of preserving the views of Islam can be seen in the Qur'an An-Nur: 30, which means: Say to believers: "Let them hold back some of their views and maintain such a penitent that they are more holy to them. Allah is well acquainted with what they do".

Said by M. Quraish Shihab in tafsir al-misbah, that in the verse contained the intent of the believers should hold some of their views, among others do not see everything that is forbidden like Body parts to be covered from woman, besides that it should maintain a whole and perfect their genitals So use it only for the lawful, and do not let the look except to who can see it. It is more sacred and honorable for them because it means closing the door of the great iniquity of adultery. ${ }^{17}$

Whereas in the Qur'an An-Nur's Letter: 31, which means: "Say to the believing woman:" Let them withhold a part of their sight, and keep their genitals, and let not their jewelry be seen, except as it is seen thereof. And let them cover the veil to their bosoms, and let not their jewels, except to their husbands, or their fathers, or the father of their husbands, or their sons, or the sons of their husbands, or their brethren, Or the sons of their brothers, or the sons of their sisters, or the women of Islam, or the slaves they have, or the servants of men who have no

15 Zainuddin Ali, Hukum Pidana Islam,(Jakarta : Sinar Grafika, 2007), p.48.

16 M. Quraish Shihab, Tafsir Al-Mihsbah Pesan, Kesan dan Keserasian Al-Qur'an, Volume 7, Jakarta : Lentera Hati, 2002, p. 458-459

17 M. Quraish Shihab, Tafsir Al-Mihsbah Pesan, Kesan dan Keserasian Al-Qur'an, Volume 9, Jakarta : Lentera Hati, 2002, p. 324 
desire (against women) Children who do not understand about Body parts to be covered from woman. And let them not strike their feet to know the jewels they hide. And repent ye unto Allah, ye faithful that ye may prosper", ${ }^{18}$

The commandment of God that both men and women maintain the view as mentioned in the above verse is because the view is the cause for adultery. The command when associated with cyber adultery is very relevant to serve as the basis for criminalization. Cyber adultery is the act of a person who can not keep his eyes to see all parts of his body, by looking at a women's picture/videos/ film and while a women is not lawful for her by over the internet.

Similarly, the command to keep the genitals and the prohibition of showing the unusual body parts visible to others is to prevent the incidence of a person's inclination towards a person who is not lawful for him, because that is the door or opportunity for adultery. Besides, by often seeing images / photos / videos / porn movies in cyberspace can also cause someone to commit adultery in cyberspace or known as cyber adultery.

In the development of Science and Technology, in fact adultery not only to be physically encountered directly but through the internet it also includes adultery, therefore Al-Qur'an Surah An-Nur: 30-31 can be used as a basis to criminalize cyber adultery including also to criminalize the making of photo / picture / film / video Porn, because actually one's genitals should not be seen / shown a person who is not lawful for him.

In Islam the command to preserve the views and the genitals is not only contained in the Qur'an but also in the hadith. Among others the hadith narrated Ahmad, namely "That view is a poisoned arrow from arrows arrow demon. And whoso turneth his sight from the beauty of a woman, because Allah alone, Allah will give in his heart a delicacy till the Day of Resurrection. "(Narrated by Ahmad) The next Hadith narrated by At Thobrani in Al mu'jam al kabir, which is "Respect your views, and guard your genitals." (Narrated At Thobrani in Al mu'jam al kabir). The hadiths narrated by Ahmad and At Turmudzi are "The most numerous people to hell are the tongue and the genitalia." (Narrated by Ahmad and At Turmudzi) ${ }^{19}$.

Based on the sound of some of these hadiths show that Islam forbids people to expose about things that can cause a person to disobey, especially related to his genitals. This means that Islam forbids a person to enjoy sexual satisfaction through the internet.

Further examined the values in Christian Protestant and Catholic religion. Christianity and Catholicism forbade adultery, included in the Gospel, Matthew 5: 28-29, "anyone who looks at women and wants him, has committed adultery with him in his heart. If your right eye causes

18 Yayasan Penyelenggara Penterjemah, Departemen Agama RI, Al-Qur'an dan Terjemahannya, p. 548

19 "Awas! Jangan Dekati Zina", in http://www.darussalaf.or.id/tafsir/awas-jangan-dekati-zina/, downloaded on8 Februari 2014 
you to sin, tear it out and throw it away, for it is better for you that one of your members perish, than to have your whole body thrown into hell. " The contents of Matthew's letter indicate that Protestant and Catholic Christianity forbade the practice of adultery, even seeing the desireble woman has been categorized as adultery in his heart. It also shows that according to Protestant and Catholic Christianity, the desire to commit adultery is the same as adultery, so it can be said that both religions prohibit acts that approve / influence / plunge someone to commit adultery ${ }^{20}$. Matthew's letter is a moral basis in criminalizing cyber adultery.

The prohibition of adultery in Hinduism, especially for Hindus in Bali, is governed in Trikaya Parisudha on Kayika, called: "Tan Paradara". This Tan Paradara by Hindus is widely interpreted in the form of seductive deeds, touching sex, having sex, even fantasizing sex with another woman / man who is not her legal / legal wife ${ }^{21}$. Based on that understanding Tan Paradara can be used as the moral basis to criminalize cyber adultery, because cyber adultery can be categorized as an act of fantasizing sex with another woman / man who is not his legal wife / husband.

The prohibition of committing adultery in Buddhism is contained in the Buddhist Pancasila. Based on Pancasila Buddhism, adultery is included in immorality, which is one of the deeds to be avoided by Buddhists. The criterion of an act is said to be immoral according to Buddhist teachings is if it meets the following four conditions ${ }^{22}$ :

1. The existence of people who are not worth being pursued.

2. Have a mind to fuck the person.

3. Attempted to fuck her.

4. Successfully fucked him.

In cyber adultery success is not in the form of physical intimacy, but virtually because it is examined from Buddhists teachings, cyber adultery is a form a moral acts that should be avoided by Buddhists. The prohibition of moral deeds in this Buddhist Pancasila can be used as a basis for criminalizing cyber adultery.

Based on the study of religious norms that exist in Indonesia, it can be said that with the moral / religious approach, has found a basis for criminalizing the actions of cyber adultary, because

20 Direct interview with Mr. Andreas Chairman of Indonesian Church Association (PDGI), as well as email interview with Romo Frans Magnis Suseno as the representative of the Catholic religion. The material is also the author of the resumes of an article titled " Pelacuran dalam Pandangan Agama Yahudi dan Kristen", http: //m.mikipedia. Downloaded on May 15, 2012

$21 \mathrm{http}: / /$ stitidharma.org/hubungan-seks-di-luar-nikah-menurut-hindu/ Downloaded on July 21, 2012, In the holy books such as Manawadharmasastra, Sarasamuscaya, and Parasaradharmasastra, sex is always regarded as a sacred thing that is only permitted after going through the process of propagation which according to Manawadharmasastra there are eight ways.

22 See in Sejarah, Teologi dan Etika Agama-agama, with introductionMoch. Dasim Mathar, Yogyakarta : Dian/Interfidei, 2005, p.296. 
the norms that exist in recognized religions in Indonesia clearly prohibit it. As stated by Roeslan $\mathrm{Saleh}^{23}$, that a criminal acts is an acts considered by society as an act that can not be done. In Indonesian society the rules of allowance and omission of an act are based on the norms and values that live within the society concerned, including religious norms.

\section{The Basis Justification Of Cyber Adultery As A Crime}

As it is known that the occurrence of a criminal offense is not always the perpetrator of doing the act by moving. There are some criminal acts committed by a person without silence. Based on the above, the action / action in criminal law is not the same as the definition or limitation of the act as generally.

According to Moeljatno criminal acts according to his intent or nature are unlawful acts. Acts that harm the community, in the sense of contradicting or inhibiting the implementation of the order in the association of society that is considered good and fair. ${ }^{24}$ According to Roeslan Saleh states that a criminal act is an act that the public perceived as an act that can not or can not be done ${ }^{25}$. Here Roeslan Saleh emphasizes the feeling of public law. Therefore, a criminal act means an act that inhibits or contradicts the achievement of the social order which the society aspires to. In criminal law to determine a criminal offense or a criminal act can be seen from its elements. There are two (2) streams in the determination of a criminal offense based on the elements of the act, namely the monistic and dualistic flows ${ }^{26}$.

Monistic flow requires that elements attached to deeds (objective elements) and elements attached to the person (subjective element) to be said to be a criminal offense and can be directly imposed criminal, while the dualistic flow says to be said to be a crime just looking On the elements attached to the act, but to be imposed a criminal, requires the fulfillment of elements inherent in the person in the act.

One element of a criminal offense is the existence of unlawful nature in a deed. In determining whether or not there is a law against the nature of action there are two teachings of nature against the law, namely Teachings of the nature of the law against the formal and teaches the nature of the law against the matriil. According to the teachings of the nature of the law against the formal it is said that the action is unlawful if an act is threatened with criminal and formulated in the law. So in this doctrine is said to be against the law when it is against the law

23 Martiman Prodjohamidjodjo, Memahami Dasar-Dasar Hukum Pidana Indonesia, Jakarta : PT Pradnya Paramita, Jakarta, 1997, p. 25

24 See in Martiman Prodjohamidjodjo, Memahami Dasar-Dasar Hukum Pidana Indonesia, Jakarta : PT Pradnya Paramita, 1997, p.16.

25 See in Martiman Prodjohamidjodjo, Ibid, Jakarta : PT Pradnya Paramita, 1997, p.16.

26 Sudarto, Hukum Pidana I, Semarang : Yayasan Sudarto, 1990, p.40-50Lihat dalam Martiman Prodjohamidjodjo, Memahami Dasar-Dasar Op.Cit, 1997, p.8. 
(written law). As for the teaching of the unlawful nature of the matriarch means the unlawful act not only that is contrary to the law (written law), but also contrary to the principles of law or values living in an unwritten society. Refers to the teaching of nature against the matrix laws, it can be said that cyber adultery is an unlawful act because it is against the values of living in an unwritten society that is religious law.

With regard to the boundaries of the recruitment, in addition to the theory of material deeds there is also the theory of action functionally. According to the theory of functional action an action does not require the perpetrator to perform a movement, in a state of silence any person can be said to do deeds if his desire to meet the elements can be realized. The use of functional theory of action has long been used in several jurisprudence, among others, in the case of electricity theft by interpreting electrical current as a good. In some articles mentioned that cyber sex is adultery. Therefore justified a policy that establishes that cyber adultery is one form of adultery.

\section{CONCLUSION}

Based on the results of research can be summarized as follows:

1. Refers to the signs to criminalize an act so that the act becomes a criminal act, cyber adultery can be criminalized into a crime because cyber adultery is an act that is not desired by the community because it is against the existing value order, the impact of losses incurred not only Material but also morally, so the results are more leverage when compared with the cost. Cyber adultery can be categorized as a criminal act because cyber adultery is illegal when examined from the teaching of nature the against material law. Whereas when viewed from the theory of functional deeds, cyber adultery is one form of adultery even though there is no physical encounter between.

2. In criminalizing cyber adultery can be used religious values that exist in Indonesia, because the religious values are a guide in the life of Indonesian people.

\section{RECOMMENDATION}

1. Cyber community raises cyber crime, in this case there must be a paradigm shift of "action", that "action" not only covers "action" materially but also includes "action" functionally.

2. In dealing with cyber crime should pay attention to jurisdiction. in this case should be used the principle of ubiquity, so it is easier to determine which country is authorized to handle the cyber crime. 
Any Ismayawati : Criminal Policies Based On Religious Values In Tackling Cyber Adultery

\section{REFERENCES}

Ali, Zainuddin, 2007, Hukum Pidana Islam, Jakarta : Sinar Grafika.

Dasim Mathar, 2005, Moch. Sejarah, Teologi dan Etika Agama-agama, with introduction, Yogyakarta : Dian/Interfidei.

Dwi Haryadi, 2013, Kebijakan Integral Penanggulangan Cyberporn di Indonesia, Yogyakarta: Penerbit Lima.

Nawawi Arief, Barda, 2006, Tindak Pidana Mayantara Perkembangan Kajian Cyber Crime di Indonesia, Jakarta: PT. Rajagrafindo Persada.

, 2010, Pendekatan Keilmuan dan Pendekatan Religius dalam Rangka

Optinalisasi Penegakan Hukum (Pidana) di Indonesia, Semarang : Badan Universitas Diponegoro Press,

2011, Pornografi Pornoaksi dan Cybersex-Cyberporn, Semarang : Pustaka Magister.

Prodjohamidjodjo, Martiman, 1997, Memahami Dasar-Dasar Hukum Pidana Indonesia, Jakarta: PT Pradnya Paramita, Jakarta.

Rahardjo, Satjipto, 2006, Membedah Hukum Progresif, Jakarta : PT Kompas Media Nusantara.

Shihab, M. Quraish, 2002, Tafsir Al-Mihsbah Pesan, Kesan dan Keserasian Al-Qur'an, Volume 7, Jakarta : Lentera Hati.

2002, Tafsir Al-Mihsbah Pesan, Kesan dan Keserasian Al-Qur'an, Volume 9, Jakarta : Lentera Hati. 